\title{
TŁUMACZENIA
}

Warszawskie Studia Pastoralne UKSW

Rok XI 2016 Nr 4(33)

Hubert Wolf

\section{OTWORZYĆ DRZWI DO KRYPTY HISTORII KOŚCIOŁA}

\author{
Hubert Wolf ${ }^{1}$, Krypta. Unterdrückte Tra- \\ ditionen der Kirchengeschichte, München \\ 2015, C. H. Beck Verlag, ss. 231, ISBN: \\ 978-3-406-67547-8.
}

Idee reform i odnowy Kościoła znajdują się w przebogatej Tradycji Kościoła i w niej można i należy poszukiwać wszelkich inspiracji dla współczesnych działań. To przekonanie stoi u źródła powstania i jest głównym motywem książki Krypta. Unterdrückte Traditionen der Kirchengeschichte (Krypta. Sttumione i zapoznane tradycje historii Kościoła) autorstwa niemieckiego profesora historii Kościoła Huberta Wolfa. „Kościół przeszłości jest zupełnie inny, jak może się nam wydawać. Przechowuje on modele, które możemy wykorzystać do budowania dziś większej demokracji, większej wolności i większego równouprawnienia” (z Wprowadzenia: „Wszyscy błądzimy”). Przez reformę rozumie Wolf przekształcenie i transformację pewnej współczesnej sytuacji, która może dokonać się w dwojaki sposób: albo

1 Autor (ur. 1959) jest od 1985 kapłanem diecezji Rottenburg-Stuttgart. Profesor Średniowiecza i Najnowszej Historii Kościoła na Uniwersytecie w Münster. Jest pierwszym teologiem uhonorowanym prestiżową nagrodą Deutsche Forschungsgemeinschaft (DGF). Miał dostęp do Archiwów Watykańskich; owocem jego wszechstronnych badań historycznych jest wiele książek, a wśród nich oparta na solidnym materiale źródłowym Die Nonnen von Sant Ambrogio (2013), uznana za swego rodzaju kościelny kryminał i okrzyknięta bestsellerem. 
reformatorskie działania skierowane będą na przywrócenie stanu poprzedniego, traktowanego jako stan idealny, albo dąży się do odnowy poprzez wypracowanie jakiejś nowej, nieznanej dotąd koncepcji. Obydwa sposoby rozumienia są uprawnione, jednak dla Wolfa ten pierwszy zdaje się być wystarczający i bardziej wprost odpowiada zasadzie Tradycji (das Prinzip der Tradition), która głosi, że „w Kościele nie ma niczego, czego nie byłoby wcześniej”. Jednocześnie dezawuuje on przekonanie, chętnie i często powtarzane przez pewne eklezjalne środowiska, że danych rozwiązań nie można przyjąć, ponieważ przeciwne im i obowiązujące obecnie koncepcje wygodnie jest im zamknąć w stwierdzeniu: „zawsze tak było”. Otóż Wolf zdecydowanie wypowiada swoje "nie” na takie dictum i przywołuje m.in. przykład biskupów wybieranych przez wszystkich, kobiety posiadające władzę iście biskupią (sic!) czy świeckich udzielających rozgrzeszenia.

Z mocą wyartykułowana przez Vaticanum II prawda o Kościele, który zawsze potrzebuje oczyszczenia (Ecclesia semper reformanda), ma swe antecedensy w historii. Nie przypadkiem więc Wolf przypomina słowa papieża Hadriana VI, odczytane w 1523 przez jego nuncjusza przed norymberskim Reichstagiem, które traktować można jako zawsze aktualne memento:

„Wiemy, że przy Stolicy Świętej już od lat miały miejsce okropne nadużycia w rzeczach świętych oraz liczne wykroczenia przeciwko przykazaniom Bożym, które przyczyniły się do degeneracji właściwie wszystkiego. Nic zatem dziwnego, że choroba zwykle rozprzestrzenia się od głowy do członków, to jest od papieży do niższych zwierzchników Kościoła. My wszyscy - wyżsi prałaci oraz zwyczajni duchowni - błądziliśmy; wszyscy dostrzegaliśmy jedynie swój interes, czego dłużej nie może już mieć miejsca, jak tylko czynić dobro i nic więcej!"3

W jedenastu obrazach-odsłonach książka przedstawia „wyparte z pamięci bądź po prostu zapomniane sposoby urzeczywistniania się katolicyzmu w dziejach, jakie mogą być przydatne we współczesnych próbach reformy Kościoła i ukazania dziś innego jego oblicza”. I tak znajdujemy tu rozwinięcie następujących zagadnień problemowych: 
„biskup wybierany przez wszystkich”, „kobiety z władzą biskupią”, „kapituła katedralna - organ kontrolny i senat biskupa”, „papież - nie wolny od błędów”, „kardynałowie - przeciwwagą władzy papieża”, "mnisi i mniszki - najwyższy autorytet wskutek radykalnego następstwa”, „gminy - prymat mniejszej jedności”, „świeccy to nie małoletnie owieczki”, „Sobór trydencki - pluralistyczny katolicyzm”, „św. Franciszek z Asyżu - opcja Kościoła ubogich” i wreszcie „na koniec - prawda, która przychodzi z historii”.

Skandali ostatnich lat, jakie wstrząsnęły Kościołem, nie sposób zdaniem Wolfa - sprowadzać jedynie do oczekiwania osobistego nawrócenia i odnowy ich sprawców. Mają one bowiem swe przyczyny także w przestarzałych strukturach związanych $\mathrm{z}$ urzędem czy w samym procesie podejmowania decyzji w Kościele. „Dlatego też wychylenie się w przeszłość zawiera w sobie pewien ładunek zapalny, ponieważ pozycja papieża, biskupów i kleru nie zawsze była tak nienaruszalna jak dzisiaj”.

Wolf zwraca się przeciwko obrazowi Kościoła, jaki przydała mu tradycjonalistyczna historiografia: chce ona bowiem widzieć jakąś absolutnie monolityczną jedność katolicyzmu - owo wielkie zwieńczenie działań Kościoła przypieczętowane dorobkiem Tridentinum, którą miał - jak widzą to tradycjonaliści - dopiero zniszczyć Sobór Watykański II. Zgodnie z tą monolityczną, a tym samym i fundamentalistyczną, wizją, msze trydenckie, trydencki ideał biskupa, trydenckie seminaria duchowne itp. miałyby być miarą wszystkiego w Kościele katolickim. Tymczasem wszystkie te „modelowe rozwiązania" są dopiero owocem wieku XIX (Sobór Watykański I), zaś sam Sobór Trydencki odznaczał się na wskroś nowatorskim, śmiałym i otwartym duchem. Na przykład typowo „trydencki” biskup był hierarchą świadomym i samodzielnym i w żaden sposób nie można widzieć w nim bezwolnego funkcjonariusza rzymskiej centrali. Co roku zwoływał synod, na którym w sposób kolegialny podejmowano decyzje wobec konkretnych potrzeb w diecezji. Natomiast „trydencki biskup” w XIX-wiecznej koncepcji nie może reprezentować innych poglądów jak papież i rzecz jasna nie jest władny zwołać $\mathrm{z}$ własnej inicjatywy żadnego synodu. Temu trydenckiemu mitowi tradycjonalistów 
autor Krypty zadaje kłam, stwierdzając, że Kościół w swej najgłębszej istocie zawsze był bardzo zróżnicowany i podlega ciągłym zmianom. „Nie było i nie ma idealnych urzeczywistnień Kościoła. Kościół zmieniał się zawsze i wciąż musi się zmieniać”.

Dziś o głębi i kierunku tych zmian zdecyduje dobrze przemyślana reforma, ale też i stopień determinacji papieża Franciszka. Z jego słów skierowanych do pracowników Kurii rzymskiej z 22 grudnia 2014 wynika, że papież dostrzega potrzebę odnowy Kościoła, a już z pewnością gruntowną reformę własnej Kurii i z drogi zmian nie zawróci. Przemawia za tym zresztą cały jego dotychczasowy pontyfikat - zarówno nauczanie, jak i styl sprawowania urzędu Piotra. O ile jednak Hadrianowi VI brakowało lojalnych i odważnych sojuszników, o których zresztą specjalnie nie zabiegał, wskutek czego nie stał się ostatecznie reformatorem, to Franciszek ma większą siłę oddziaływania, choćby przez dostęp do współczesnych środków przekazu. W jednym z wywiadów ${ }^{2}$ udzielonych po publikacji Krypty Wolf zdaje się sugerować, że dodatkową pomocą w realizacji franciszkowego programu reform może okazać się... jego ostatnia książka. Wystarczy bowiem sięgnąć po któryś z modeli, jakie należą do przebogatego skarbca historii Kościoła. Nie trzeba przy tym - jak zapewnia nie bez satysfakcji - zrywać z Tradycją, a jedynie zaaplikować któreś z licznych rozwiązań obecnych w jego, jako historyka, przedstawieniach wyników eksploracji tej Tradycji.

Wśród takich rozwiązań, które byłyby nawiązaniem do starej tradycji Kościoła, a jednocześnie wpisywałyby się w aktualne jego potrzeby, sytuuje Wolf zagadnienie związane z większą jeszcze potrzebą waloryzacji pozycji kobiet w Kościele.

Od siebie dodajmy w tym miejscu, że owo „wołanie o więcej dla kobiet" uznać wypada za specificum niemieckiej czy szerzej:

2 Zob. Die verlorene Macht der Äbtissinnen. Interviev mit Hubert Wolfvon Joachim Frank, («http://www.fr-online.de/kultur/interview-hubert-wolf-die-verlorene-macht-der-aebtissinnen,1472786,29619704.html»dostęp:30.07.2016). 
niemieckojęzycznej teologii katolickiej i przedmiot jej szczególnego zainteresowania, któremu z predylekcją się oddaje ${ }^{3}$.

Argumentem na rzecz ewentualnego uczynienia zadość tym wołaniom jest w przekonaniu autora Krypty fakt, że jeszcze 800 lat temu w niektórych zakonach żeńskich opatki miały władzę, jaka na ogół zarezerwowana była (jest) biskupowi. Średniowieczne opatki mianowały bowiem proboszczów, wydawały katechizmy, udzielały zgody na zawarcie małżeństwa, a w razie potrzeby dyspensowały od przeszkód małżeńskich, przepowiadały Ewangelię i głosiły kazania podczas Mszy św. Pewnego smaku temu obrazowi z odległej przeszłości przydaje dziś okoliczność, że papież Franciszek na audiencji (maj 2016) udzielonej kilkuset żeńskim wyższym przełożonym zakonnym zapowiedział zamiar powołania specjalnej komisji teologicznej, której zadaniem jest zbadanie możliwości przyznana kobietom święceń diakońskich. Już sam ten fakt otwiera - nieoczekiwane jak dotąd możliwości. O ile bowiem - jak zauważa Hubert Wolf w wywiadzie udzielonym Katholische Nachrichten Agentur (KNA) ${ }^{4}$ - „pewien prominentny Kardynał (chodzi zapewne o Gerharda Ludwiga Müllera, prefekta Kongregacji Nauki Wiary - przyp. R. K.), powołując się na decyzję Jana Pawła II z 1994, wykluczającego możliwość święceń kapłańskich dla kobiet, wykluczył ją również w przypadku ich święceń diakońskich. Jeśli jednak tak miałoby być, jak chce Kardynał, wówczas nie byłoby potrzeby powoływania żadnej komisji. Skoro zaś Papież jej się domaga, istnieje możliwość, że wyniki tej komisji doprowadzą do zmian”. Tak więc Franciszek zainicjował dyskusję, którą wielu uznało już za zamkniętą.

${ }^{3}$ Zob. w związku z tym, Rafał J. Kupiszewski, Dietmar W. Winkler (Hg.), Diakonat der Frau. Befunde aus biblischer, patristischen, ostkirchlicher. Liturgischer und systematisch-theologischer Perspektive, Wien 2013, 2. Aufl., Lit Verlag, ss. 155, „Warszawskie Studia Pastoralne” 2016, nr 2(31), s. 171-175.

4 Kirchenhistoriker Wolf zur Debatte um Diakonat der Frau: „Franziskus hat die Diskussion wieder eröffnet". Das Interview führte Christian Wölfel, http://www. domradio.de/themen/papst-franziskus/2016-05-14/kirchenhistoriker-wolf-zur-debatte-um-diakonat-der-frau (dostęp: 02.08.2016). 
Wolf wskazuje też na przykład włoskich kartuzek, które podczas liturgii mszalnej mogą głosić Ewangelię. W ich przypadku do dzisiaj stosowany jest formularz, jakim biskup posługuje się udzielając święceń diakonatu mężczyznom.

Bogate spectrum tematyczne podjęte w Krypcie każe z wdzięcznością przyjąć książkę i uczynić ją przedmiotem dalszej i bardziej pogłębionej refleksji. Recepcja anonsowanej tu publikacji może przysłużyć się dobrze Kościołowi w drodze do jego odnowy w oparciu o „naukę z przeszłości” oraz complexio oppositorum.

Rafał J. Kupiszewski 